\title{
大腸穿孔患者の腹部CTを用いた大腰筋断面積と歩行能力と の関連
}

\author{
渡辺 伸一 $* 1$ 大野 美香*2 森田 恭成*2 \\ 鈴木 秀一 $* 2$ 染矢富士子 $* 3$
}

\begin{abstract}
要約：【目的】大腸穿孔患者の退院時の歩行自立の可否と腰部主要筋の断面積との関連性を明 らかにすることを目的とした。【方法】調査対象は，外科で大腸穿孔に対して緊急開腹術を施 行し, 術後ICU管理を行った 63 症例のうち, 除外基準に相当する 31 例を除いた 32 例に対し, 歩行自立群 $(\mathrm{n}=21)$ と歩行非自立群 $(\mathrm{n}=11)$ の 2 群に分類した。【結果】ロジスティック回帰 分析にて歩行自立と関連する要因として抽出された項目は, APACHE II スコア, 転帰, 大腰 筋面積の 1 日当たりの変化率であった。【結論】ICU管理中での大腰筋断面積の低下はICU 退室 後の歩行能力の獲得に対して悪影響を及ぼす可能性があるため, できる限り ICUでの早期離 床を目指し，離床が困難な症例については，ベッド上で行える筋力トレーニングを積極的に 行うことで, 大腰筋の筋力低下を予防する必要があると思われた。
\end{abstract}

Key words: (1) colon perforation, (2) muscle weakness, (3) psoas major, (4)early mobilization

\section{研究の目的}

高齢者人口の増加に伴い, 高齢患者の手術, 麻酔症 例は増加している。一般に, 高齢者の緊急開腹手術周 術期に呼吸不全を合併すると重篤な状態になることが 多く, 人工呼吸器管理が必要となる。しかし, 人工呼 吸器管理に伴うべッド上安静により長期間不動状態に なると，全身的な筋力低下 (ICU-acquired weakness, ICUAW）を起こすと言われている1)。ICUAW の原因 として, ベッド上安静のほか, 多臟器障害, 高血糖, 又 テロイド・筋弛緩薬・鎮静薬の使用が考えられてい る2)。そのため, 原疾患の治療, 敗血症や多臟器障害 の管理，血糖管理，ステロイド・筋弛緩薬・鎮静薬の 使用を最小限にすることと同時に, 早期離床が ICUAW の予防や治療に重要と言われている31,4)。し かし, ICUAWの診断は, 急性期には鎮静, 脳症, せん 妄など筋力評価に支障をきたす多くの因子が存在する ので困難である5)。森ら ${ }^{6)}$ は, がん患者に扔ける大腰 筋断面積の減少について腹部 C T 画像を用いて検討し ており, CTによりある一定レベルの筋断面積の定量 的な評価が可能となってきている。
大腸穿孔は, 沉発性腹膜炎から敗血症, 多臟器障害 に至る予後不良な救急疾患である7)。大腸穿孔の治療 としては手術治療が絶対的適応であるが, 基礎的体力, 回復力が低い高齢者に発症することが多く, 急激に腹 膜炎から敗血症を生じて多臟器障害に至るなど重篤な 病態を示すことがある。しかし，一般的に大腸穿孔症 例の大多数では, 術後人工呼吸器管理下で鎮静状態に あることから, 廃用症候群による機能障害や動作能力 障害を生じるリスクは大きく8), リハビリテーション が長期に必要になることがある9 。本研究では大腸穿 孔術後のICUAWに着目し, 腹部C T を用いて腰部主 要筋の骨格筋断面積を定量的に評価し, 歩行自立との 関連性を明らかにすることを目的とした。

\section{方 法}

\section{1）研究デザインと対象}

研究デザインは後ろ向き観察研究とした。本研究の 調查期間は 2010 年 4 月 1 日から 2015 年 3 月 31 日まで とした。調查対象は, 外科で大腸穿孔に対して緊急開 腹術を施行し，術後ICU管理を行った 63 症例とした。 そのうち, 18 歳未満, 入院前より屋内歩行に介助を要

\footnotetext{
*1独立行政法人国立病院機構名古屋医療センターリハビリテーション科, $* 2$ 同 集中治療科

（ ○ 454-0902 愛知県名古屋市中区三の丸4-1-1）

*3 金沢大学大学院医薬保健学総合研究科保健学専攻 ( T 920-0942 石川県金沢市小立野5-11-80)

受付日 2015 年 5 月 26 日 採択日 2016 年 1 月 19 日
} 


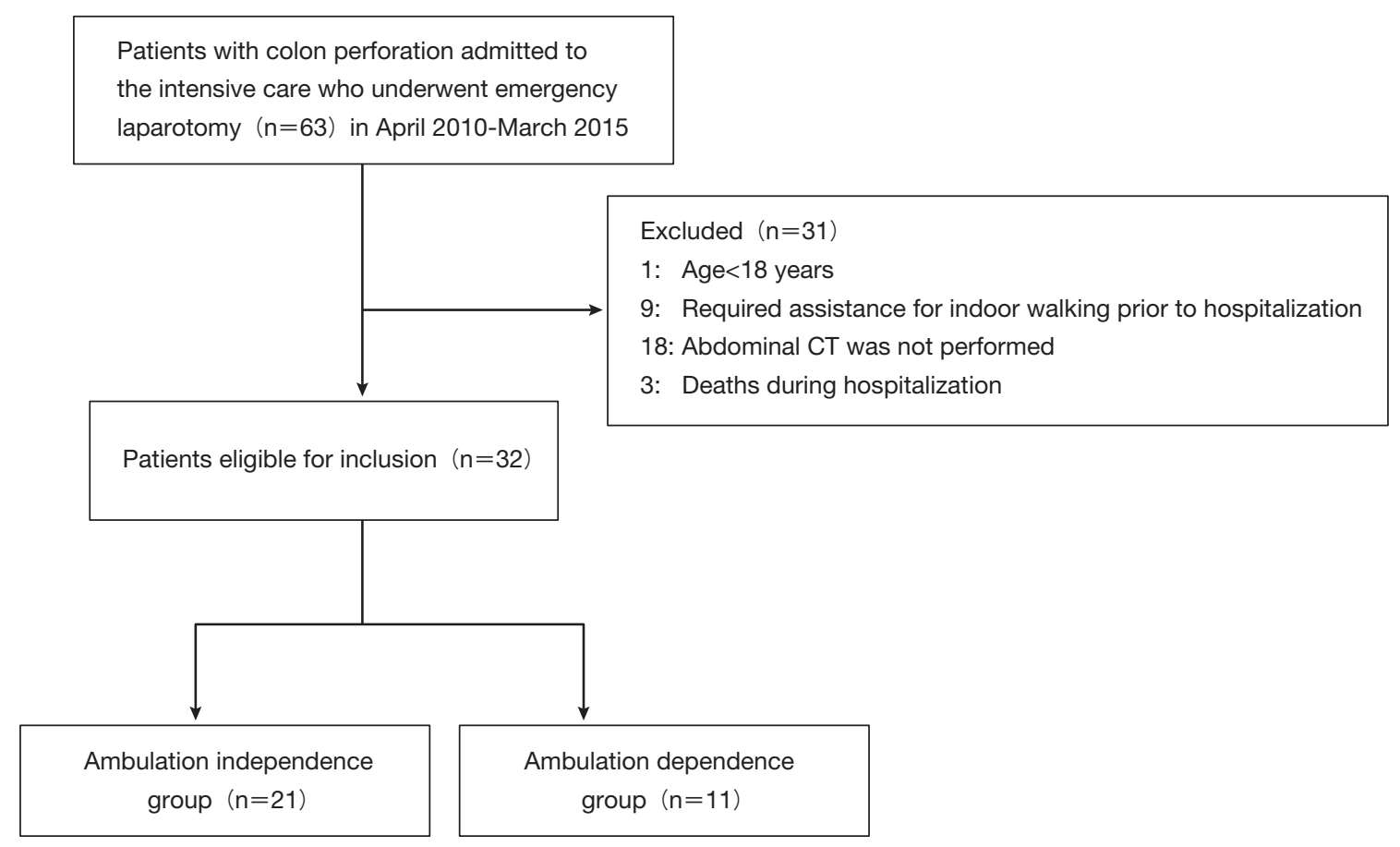

Fig. 1 Flow of patients throughout the study

した患者, 術直前および術後 1 力月以内に腹部 CTが 撮影されていなかった患者, 入院中に死亡した患者 31 症例を除外した (Fig. 1)。

本研究では, 退院時での歩行自立の可否をエンドポ イントとして, 歩行自立群および歩行非自立群の 2 群 に分類した。歩行自立の判断基準は, 理学療法士およ び看護師のいずれかの主観的判断により, $50 \mathrm{~m}$ 以上 歩行が可能でベッドからトイレまでの歩行が可能と判 断された場合とした。また, 実際, 病棟でのトイレ歩 行で監視や介助が必要であった場合は不可能と定義し た。

\section{2) 調査項目}

本研究での調査項目は, (1)患者背景・術前因子, (2) 術後経過因子, (3)腰部主要筋の断面積の 3 要因とした。

(1)患者背景・術前因子では, 性別, 年齢, 身長, 体重, BMI, 穿孔の原因, 穿孔部位, 術式, 手術時間, 出血量, 糖尿病の割合, APACHE II スコア10), 第 1 病日の SOFA スコア ${ }^{11)}$, 入院前 Barthel index (BI) ${ }^{12)}$, 白血球, 血小板, base excess (BE), 血清アルブミン, 血清クレ アチニン, $\mathrm{P} / \mathrm{F}$ 比について診療録より調査した。

(2)術後経過因子として, 対象患者を退院時まで追跡 し, ICU入室後 28 日間における ventilator-free days (VFD) ${ }^{13)}$, ICU在室日数, 在院日数, 初回端座位まで の日数, エンドトキシン吸着〔polymyxin B immobilized fiber column direct hemoperfusion (PMX-DHP) を使用了および持続的血液透析濾過 (continuous hemodiafiltration, CHDF) の割合, 術後ICUにおける 敗血症および播種性血管内凝固 (disseminated intravascular coagulation, DIC) の割合, 薬物療法としてド パミン, ドブタミン，ノルアドレナリンの持続投与の 割合を調查した。

DIC については日本救急医学会の急性期 DIC 診断基 準14)を用いて, 4点以上をDICありとした。ADL (activities of daily living) と歩行能力の評価は, 入院 前と退院時の能力を調査した。入院前の評価は, 入院 日から 1 カ月前までを振り返り, 一番状態の良かった 時点での ADLと歩行能力を本人または家族などから 聴取した。

(3)腰部主要筋の断面積では, 手術直前および手術後 1 カ月における腹部 CT の腸骨最頭側レベルの横断像 上で, 左右の大腰筋の輪郭を region of interest (ROI) としてトレースし, 面積の合計值を算出した。同様に, 比較のため大腰筋以外の腰部の主要な筋肉である脊柱 起立筋の面積も同時に計測した (Fig. 2)。宵柱起立筋 の断面積は, 最長筋, 多裂筋, 棘筋を一塊に胸部 CT 画 像上で評価した。CT撮影の条件はX線 $120 \mathrm{kV}, 300$ $\mathrm{mA}$ ，スキャン時間 4.0 秒，スライス幅 $1 \mathrm{~mm}$ であった。 撮影は医師の指示のもと診療放射線技師により行われ た。筋断面積は, 上記条件で撮影したCT画像をパー ソナルコンピュータに取り込み, トラックボールを用 いて, 各筋の外周をトレースして求めた。2回ずつ測 定し, その平均值を測定值として採用した。画像解析 

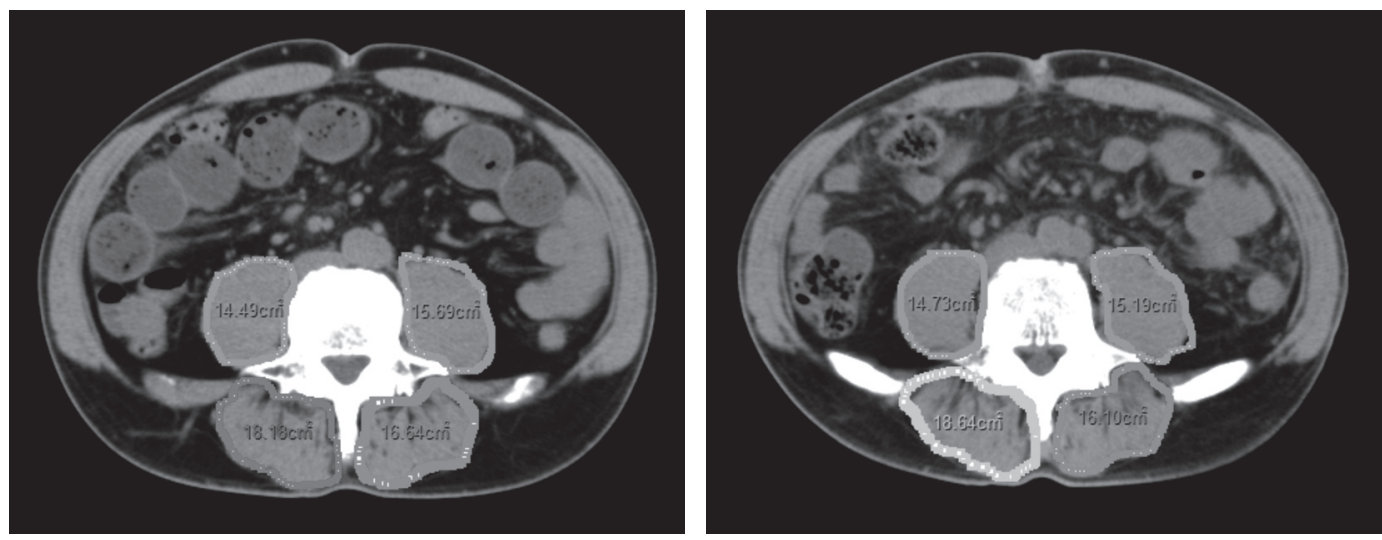

Fig. 2 Muscle cross-sectional area measurement example of the psoas muscle and erector spinae on lumbar CT Regarding the cross-sectional areas of major lower back muscles, cross-sectional images at the most rostral point of the ilium, obtained by abdominal CT immediately before and 1 month after surgery, were used to trace the outlines of the left and right psoas major and erector spinae as regions of interest (ROI) and calculate the total value of these areas.

ソフトはImageJ 1.48u(NIH, USA)を使用した。さ らに術後1日当たりの断面積の変化率〔(術後筋断面 積 -術前筋断面積 $) /$ 術前筋断面積 × 100/日数]を算 出した。

\section{3) 統計学的分析}

まず, 歩行自立群と歩行非自立群の 2 群に分類して (1)患者背景・術前因子, (2)術後経過因子, (3)腰部主要 筋の筋断面積の 31 項目に対して, 対応のないt検定, $\chi^{2}$ 検定を実施した。筋断面積測定の検者内信頼性は, 級内相関係数 (intraclass correlation coefficients, ICC) を用いて検討した。さらに, 歩行自立と関連する要因 を多変量解析にて検証するために, 歩行自立の可否を 目的変数として, 2 群間の比較で有意差を認めた項目 を説明変数とした尤度比を用いた変数増加法による口 ジスティック回帰分析を行った。この際, 多重共線性 を考慮するため, Spearmanの順位相関倸数を用いた 検討を行い, 相関係数の絶対值が 0.7 以上となった場 合は，臨床的に有意義と考えられる変数を採用して検 討を行った。統計処理にはSPSS Statistics 21.0を用 い, 有意水準は $5 \%$ 未満とした。

なお, 本研究は当院倫理・利益相反委員会の承認 （承認番号：2015-11）を受けるとともに, 個人情報の 取り扱いには十分に留意し検討を行った。

\section{結 果}

患者背景・術前因子に関する項目をTable 1 に示 す。歩行自立群は歩行非自立群と比較して, APACHE II スコアにて有意に低值であり $(P<0.01)$ ，血清アル ブミンにて有意に高值であった $(P=0.02)$ 。

術後経過因子に関する項目を Table 2 に示す。歩行
自立群は歩行非自立群と比較して, 初回端座位までの 日数 $(P<0.05)$ が有意に短縮していた。

大腰筋断面積および薮柱起立筋断面積の $\operatorname{ICC}(1,2)$ は0.920 0.996であり, 高い再現性が確認された (Table 3)。

腰部主要筋の面積值の比較を Table 4 に示す。歩行 自立群は歩行非自立群と比較して, 有意に術後大腰筋 面積 $(P<0.01)$ 抢よび大腰筋面積の 1 日当たりの変化 率 $(P<0.01)$ が増加していた。脊柱起立筋面積につい ては術前および術後の筋断面積に有意差を認めなかっ た。

多重ロジステイック回帰分析の結果を Table 5 に示 す。その結果, APACHE II スコア, 血清アルブミン, 初回端座位までの日数, 大腰筋面積の 1 日当たりの変 化率の 4 項目を説明変数として投入した。

ロジスティック回帰分析の結果, 歩行自立と関連す る要因として抽出された項目は, APACHE II スコア, 大腰筋面積の 1 日当たりの変化率であり，それぞれの 調整オッズ比はAPACHE II スコアが $0.808(P=$ $0.017)$, 大腰筋面積の 1 日当たりの変化率が $13.3(P=$ 0.032) であった。モデル $\chi^{2}$ 検定の結果は $P<0.01$ で 有意であり, 各変数も有意であった。Hosmer Lemeshowの検定結果は $P=0.974 て ゙$ 問題はなく, 判 別的中率も $79.6 \%$ と比較的良好な結果であった。

\section{考 察}

本研究では歩行自立群はAPACHE II スコアが有意 に低值であり，血清アルブミンが有意に高值であった。 また, 歩行自立群は初回端座位までの日数を短縮して おり, 大腰筋面積の 1 日当たりの変化率においても有 
Table 1 Comparison of the items related to the background and preoperative factor

\begin{tabular}{|c|c|c|c|}
\hline & Independence $(\mathrm{n}=21)$ & Dependence $(\mathrm{n}=11)$ & $P$ values \\
\hline Sex (male/female) & $15 / 6$ & $6 / 5$ & $0.44^{b)}$ \\
\hline Age (year) & $66.7 \pm 12.6$ & $69.7 \pm 16.5$ & 0.57 a) \\
\hline Height $(\mathrm{cm})$ & $161.7 \pm 9.6$ & $156.3 \pm 10.6$ & $0.17^{\text {a) }}$ \\
\hline Weight $(\mathrm{kg})$ & $58.8 \pm 14.3$ & $50.9 \pm 16.5$ & 0.26 a) \\
\hline BMI & $22.3 \pm 4.1$ & $20.4 \pm 4.6$ & $0.16^{\text {a) }}$ \\
\hline Cause of perforation & & & $0.38^{b)}$ \\
\hline Colon cancer & 5 & 5 & \\
\hline Diverticulum & 5 & 2 & \\
\hline Idiopathic & 7 & 3 & \\
\hline Other & 4 & 1 & \\
\hline Perforation sites & & & $1.00^{b)}$ \\
\hline Right colon & 12 & 7 & \\
\hline Left colon & 9 & 4 & \\
\hline Surgical procedures & & & $0.52 \mathrm{~b})$ \\
\hline Hartmann & 7 & 6 & \\
\hline $\mathrm{RPA}$ & 6 & 1 & \\
\hline Colostomy & 5 & 3 & \\
\hline Other & 3 & 1 & \\
\hline Operation time $(\mathrm{min})$ & $209.5 \pm 99.2$ & $216.3 \pm 103.7$ & 0.86 a) \\
\hline Amount of bleeding $(\mathrm{m} l)$ & $201.4 \pm 173.7$ & $238.9 \pm 286.6$ & 0.37 a) \\
\hline Sepsis & $11(52.4 \%)$ & $8(72.7 \%)$ & $0.27 \mathrm{~b})$ \\
\hline Diabetes & $6(28.6 \%)$ & $6(54.5 \%)$ & $0.15^{b)}$ \\
\hline APACHE II score & $18.1 \pm 6.8$ & $25.3 \pm 6.2$ & $<0.01^{\text {a) }}$ \\
\hline SOFA score & $6.1 \pm 3.2$ & $6.0 \pm 2.4$ & 0.89 a) \\
\hline Prehospital BI & $97.6 \pm 5.6$ & $91.4 \pm 7.8$ & $0.08^{\text {a) }}$ \\
\hline $\mathrm{WBC}\left(\times 10^{2} / \mu l\right)$ & $103.6 \pm 55.6$ & $86.4 \pm 43.5$ & 0.09 a) \\
\hline $\operatorname{Plt}\left(\times 10^{4} / \mu l\right)$ & $22.9 \pm 11.4$ & $19.6 \pm 10.4$ & 0.22 a) \\
\hline $\mathrm{BE}(\mathrm{mmol} / l)$ & $-3.0 \pm 4.1$ & $-3.0 \pm 5.2$ & $0.98^{\text {a) }}$ \\
\hline $\operatorname{Albumin}(\mathrm{g} / \mathrm{d} l)$ & $3.3 \pm 0.7$ & $2.7 \pm 0.7$ & $0.02^{\text {a) }}$ \\
\hline Serum $\operatorname{Cr}(\mathrm{mg} / \mathrm{d} l)$ & $1.6 \pm 1.3$ & $1.5 \pm 1.8$ & $0.76^{\text {a) }}$ \\
\hline $\mathrm{P} / \mathrm{F}$ ratio & $337.2 \pm 63.5$ & $293.8 \pm 102.7$ & $0.15^{\text {a) }}$ \\
\hline
\end{tabular}

The data represent the means $\pm \mathrm{SD}$, or the number of patients.

a): unpaired t-test, b): $\chi^{2}$ test.

$\mathrm{BE}$, base excess; $\mathrm{BI}$, Barthel index; RPA, resection and primary anastomosis.

Table 2 Comparison of factors related to the postoperative course

\begin{tabular}{llll}
\hline \hline & Independence $(\mathrm{n}=21)$ & Dependence $(\mathrm{n}=11)$ & $P$ values \\
\hline VFD (day) & $24.1 \pm 3.9$ & $21.8 \pm 5.4$ & $0.22^{\mathrm{a})}$ \\
ICU stay (day) & $4.6 \pm 3.2$ & $7.9 \pm 5.5$ & 0.09 a) \\
Length of stay (day) & $49.0 \pm 25.5$ & $58.2 \pm 33.6$ & $\left.0.43^{\mathrm{a}}\right)$ \\
First day out of bed (day) & $7.2 \pm 6.1$ & $12.5 \pm 8.9$ & $<0.05^{\mathrm{a})}$ \\
DIC & $7(33.3 \%)$ & $7(63.6 \%)$ & $0.10^{\mathrm{b})}$ \\
PMX-DHP & $10(47.6 \%)$ & $5(45.5 \%)$ & $1.00^{\mathrm{b})}$ \\
CHDF & $2(9.5 \%)$ & $2(18.2 \%)$ & $0.59 \mathrm{~b})$ \\
Vasopressor administration & $14(66.7 \%)$ & $8(72.7 \%)$ & $\left.0.73^{\mathrm{b}}\right)$ \\
CT scanning interval (day) & $16.7 \pm 5.2$ & $14.9 \pm 5.2$ & $\left.0.56^{\mathrm{a}}\right)$ \\
\hline
\end{tabular}

The data represent the means $\pm \mathrm{SD}$, or the number of patients. a): unpaired t-test, b): $\chi^{2}$ test.

CHDF, continuous hemodiafiltration; DIC, disseminated intravascular coagulation; PMX-DHP, polymyxin B immobilized fiber column direct hemoperfusion; VFD, ventilator-free days. 
日集中医誌 J Jpn Soc Intensive Care Med Vol. 23 No. 5

Table 3 Measurements of reliability $\operatorname{ICC}(1,2)(\mathrm{n}=32)$

\begin{tabular}{lcc}
\hline \hline & Preoperative & Postoperative \\
\hline Psoas major CSA & 0.996 & 0.995 \\
Erector spinae CSA & 0.945 & 0.920 \\
\hline
\end{tabular}

CSA, cross-sectional area; ICC, intraclass correlation coefficients.

Table 4 Comparison of the area of the major lumbar muscle

\begin{tabular}{lllllll}
\hline \hline & \multicolumn{3}{c}{ Ambulation independence $(\mathrm{n}=21)$} & \multicolumn{2}{l}{ Ambulation dependence $(\mathrm{n}=11)$} \\
\cline { 2 - 7 } & $\begin{array}{l}\text { Pre- } \\
\text { operative }\end{array}$ & $\begin{array}{l}\text { Post- } \\
\text { operative }\end{array}$ & $\begin{array}{l}\text { Rate of change } \\
(\% / \text { day })\end{array}$ & $\begin{array}{l}\text { Pre- } \\
\text { operative }\end{array}$ & $\begin{array}{l}\text { Post- } \\
\text { operative }\end{array}$ & $\begin{array}{l}\text { Rate of change } \\
(\% / \text { day })\end{array}$ \\
\hline Psoas major CSA $\left(\mathrm{cm}^{2}\right)$ & $16.1 \pm 6.0$ & $16.2 \pm 5.6$ & $0.29 \pm 0.9$ & $14.4 \pm 6.3$ & $12.0 \pm 4.2^{*}$ & $-0.90 \pm 1.5^{*}$ \\
Erector spinae CSA $\left(\mathrm{cm}^{2}\right)$ & $32.8 \pm 8.7$ & $32.0 \pm 8.8$ & $-0.11 \pm 0.5$ & $28.7 \pm 11.5$ & $26.3 \pm 9.5$ & $-0.53 \pm 0.7$ \\
\hline
\end{tabular}

The data represent the means $\pm \mathrm{SD}$.

Unpaired t-test, $*: P<0.01$.

CSA, cross-sectional area.

Table 5 Multivariate analysis of factors associated with ambulation independence in colon perforation patients $(n=32)$

\begin{tabular}{lccc}
\hline \hline Variable & OR & $95 \% \mathrm{CI}$ & $P$ values \\
\hline APACHE II score & 0.808 & $0.678 \sim 0.963$ & 0.017 \\
Rate of change of the psoas major CSA (\%/day) & 13.3 & $1.257 \sim 142.187$ & 0.032 \\
\hline
\end{tabular}

Hosmer-Lemeshow, goodness-of-fit test $\chi^{2}=11.13, P=0.974$.

意に改善していた。ロジスティック回帰分析にて検証 した結果, 歩行自立群と関連する要因として抽出され た項目は, APACHE II スコア, 大腰筋面積の 1 日当た りの変化率であった。

APACHE II スコアは, ICU入室患者における病態 の重症度を客観的に評価するために作られた予後予測 法であり, 本邦においても多く使用されている。一方, 大腸穿孔の予後因子として報告されている15), 年䶕, 穿孔部位, 白血球数, 血小板数, BE, 血清クレアチニ ンなどは有意差を認めなかった。このことから, 大腸 穿孔の歩行自立の可否の判定では, APACHE II スコ アなどの総合的な数值は考慮されるとしても, 疾患の 重症度や個々のパラメータについては寄与しないこと が示唆された。また, 血清アルブミン值は炎症にも反 応するため, 単独での栄養評価は難しいが, 本研究で は血清アルブミン值が歩行自立群で有意に高值であっ たことから, その他に血液生化学所見や身体計測など 栄養状態も考慮する必要性が示唆された。

腰部主要筋の筋断面積では, 腰部画像上で骨格筋の 外周をトレースすることで計測される大腰筋の面積值
は, 大腸穿孔症例における自立歩行の可否に影響する ことが示された。大腸穿孔患者の筋力低下には手術に よる侵襲や多臓器障害, 高血糖, ステロイド・筋弛緩 薬・鎮静薬などが影響すると考えられる。本研究でも 大腰筋の断面積減少は, ICUAWによる全身性の筋力 低下を反映するものと思われた。ICUAWの筋力評価 には, 握力測定やMedical Research Council (MRC) scor $\mathrm{e}^{16)}$ が用いられるが, ICUにおいては鎮静やせん 妄などの影響もあり正確に評価することが難しい。本 研究で使用したCTから筋肉量を評価する方法では, 腰部主要筋の筋断面積を客観的に評価することが可能 であった。また, 下部消化管穿孔では, 治療効果など の判別を CT画像で行うことが多く, 診断のために使 用する CT 画像から評価が可能で, 追加で画像撮影す る必要がなく, 一般診療にも普及しやすい有用な方法 であると考えられる。

大腰筋面積の変化率は, 脊柱起立筋の変化率よりも 歩行自立との関連性が強かった。大腰筋は腰椎, 骨盤, 股関節の動的安定化に寄与し, 股関節屈曲の主動作と して作用する。また, 大腰筋断面積は加歯とともに低 
下し 17$)$, 高齢者の歩行機能低下と転倒予防の面からも 注目されている18)。本研究の結果から, 脊柱起立筋 についてはベッド上においても head upなど抗重力位 をとることで，ある程度は維持できると思われた。し かし, 大腰筋については姿勢保持のみではなく歩行時 の動作筋としても作用するため, 立位, 歩行など離床 を中心とした介入が必要ではないかと考えた。

Schefold ら 2) は, ICUにて早期から運動療法を開始 した介入群において, 退院時 ADLや歩行距離の増加 を認め, さらにせん妄についても減少したと報告して いる。本研究でも, 歩行自立群にて初回端座位までの 日数が短縮しており, 大腰筋面積の変化率が最も高い オッズ比を示したことを考慮すると, 大腸穿孔患者へ の歩行自立を目標とする場合, ICU管理中での大腰筋 断面積の低下はICU 退室後の歩行能力の獲得に対し て悪影響を及ぼす可能性がある。よって, できる限り ICUでの早期離床を目指し, 離床が困難な症例につい てはベッド上で行える筋力トレーニングを積極的に行 うことで大腰筋の筋力低下を予防する必要があると思 われた。

本研究にはいくつかの限界が含まれ, 結果の解釈に は注意すべき点がある。本研究は 1 施設における調查 であり, 調査期間も限定されていることが挙げられる。 また, 本研究は後方視的研究のため, ICUAWの診断 に必要な筋力評価について十分に行えておらず, 大腰 筋面積と筋力およびICUAW の有無に関連する検討が できていない点が挙げられる。さらに, 本研究におけ るCT撮影間隔は個々の症例ごとに差があり一定の間 隔で行われていないため, 撮影日の違いが結果に影響 を及ぼしていた可能性も考えられる。今後, 前方視的 に症例を集積し, 撮影間隔を一定とし, 術前の運動機 能や術後の栄養管理についても詳細に把握した上で, 大腸穿孔患者への運動療法や活動性と大腰筋面積の減 少の関連について検討する必要があると考えられた。 また, 筋断面積について, 炎症による浮腫などの影響 や筋内脂肪などにより過大評価している可能性もあ り, 今後は筋の量のみでなく質についても検討する必 要がある。

\section{結 論}

本研究は, 大腸穿孔患者の退院時の歩行自立の可否 と術前・術後の経過因子および腰部主要筋との関連性 を明らかにすることを目的とした。結果より, ロジス ティック回帰分析にて歩行自立と関連する要因として 抽出された項目は, APACHE II スコア, 大腰筋面積の 1日当たりの変化率であった。
ICU 管理中での大腰筋断面積の低下は ICU 退室後の 歩行能力の獲得に対して悪影響を及ぼす可能性がある ため, できる限り ICUからの早期の離床を目指し, 離 床が困難な症例についてはベッド上で行える筋力ト レーニングを積極的に行うことで大腰筋の筋力低下を 予防する必要があると思われた。

本稿のすべての著者には, 規定されたCOIはない。

\section{文 献}

1) Truong AD, Fan E, Brower RG, et al. Bench-to-bedside review: mobilizing patients in the intensive care unit--from pathophysiology to clinical trials. Crit Care 2009;13:216.

2) Schefold JC, Bierbrauer J, Weber-Carstens S. Intensive care unit-acquired weakness (ICUAW) and muscle wasting in critically ill patients with severe sepsis and septic shock. J Cachexia Sarcopenia Muscle 2010;1:147-57.

3) Bailey P, Thomsen GE, Spuhler VJ, et al. Early activity is feasible and safe in respiratory failure patients. Crit Care Med 2007;35:139-45.

4) Burtin C, Clerckx B, Robbeets C, et al. Early exercise in critically ill patients enhances short-term functional recovery. Crit Care med 2009;37:2499-505.

5) Fan E, Zanni JM, Dennison CR, et al. Critical illness neuromyopathy and muscle weakness in patients in the intensive care unit. AACN Adv Crit Care 2009;20:243-53.

6) 森 直治, 東口高志, 伊藤彰博, 他. “がん患者に抢ける CT大腰筋面積測定の臨床的意義”。静脈経腸栄養 2014;29: 1211-7.

7) Tan KK, Zhang J, Liu JZ, et al. Right colonic perforation in an Asian population: predictors of morbidity and mortality. J Gastrointest Surg 2009;13:2252-9.

8) Brahmbhatt N, Murugan R, Milbrandt EB. Early mobilization improves functional outcomes in critically ill patients. Crit Care 2010;14:321.

9) Dowdy DW, Eid MP, Dennison CR, et al. Quality of life after acute respiratory distress syndrome: a metaanalysis. Intensive Care Med 2006;32:1115-24.

10) Knaus WA, Draper EA, Wagner DP, et al. APACHE II: a severity of disease classification system. Crit Care Med 1985;13:818-29.

11) Vincent JL, Mendonça A, Cantraine F, et al. Use of the SOFA score to assess the incidence of organ dysfunction/ failure in intensive care units: results of a multicenter, prospective study. Working group on "sepsis-related problems" of the European Society of Intensive Care Medicine. Crit Care Med 1998;26:1793-800.

12) Katz PP. Measures of Adult General Functional Status. Arthritis \& Rheumatism 2003;49:S15-27.

13) 小林秀嗣, 内野滋彦, 遠藤新大, 他. シベレスタット使用 中止による敗血症性急性肺傷害症例の予後変化. 日集中医 誌 2012;19:609-15.

14) 早川峰司, 丸藤 哲. 急性期 DIC 診断基準と治療は? . 救 急・集中治療 2009;21:1095-102.

15) 鹿股宏之, 小林健二, 加瀬建一, 他. 大腸穿孔の予後因子 とエンドトキシン吸着療法の適用についての検討. 日腹部 救急医会誌 2009;29:957-63.

16) Florence JM, Pandya S, King WM, et al. Intrarater reliability of manual muscle test (Medical Research Council scale) grades in Duchenne's muscular dystrophy. 
Phys Ther 1992;72:115-22.

17) 金 俊東，久野譜也，相馬りか，他．加齢による下肢筋量

の低下が歩行能力に及ぼす影響. 体力科学 2000;49:589-96.
18) 金 俊東，大島利夫，馬場紫乃，他. 長期間トレーニング を継続している高齢アスリートの筋量と歩行能力の特徵. 体力科学 2001;50:149-58.

\title{
Abstract \\ The relationship between cross-sectional area of the psoas major muscle and ambulation ability using abdominal $C T$ in colon perforation patients
}

\author{
Shinichi Watanabe*1, Mika Ohno*2, Yasunari Morita*2, Shuichi Suzuki*2, Fujiko Someya*3 \\ ${ }^{* 1}$ Department of Rehabilitation, ${ }^{* 2}$ Emergency Medicine Intensive Care Unit, National Hospital Organization, Nagoya Medical Center \\ ${ }^{* 3}$ Pharmaceutical and Health Sciences, School of Health Sciences, Kanazawa University, College of Medical \\ *1,2 4-1-1 Sannomaru, Naka-ku, Nagoya, Aichi 454-0902, Japan \\ ${ }^{* 3}$ 5-11-80 Kodatsuno, Kanazawa, Ishikawa 920-0942, Japan
}

Purpose: This study was conducted to examine the relationship between ambulation independence and crosssectional area of the lumbar major muscle in patients with colon perforation. Methods: We retrospectively examined the cases of 32 colon perforation patients who underwent emergency laparotomy. We divided the patients into two groups: ambulation independence $(n=21)$ and ambulation dependence $(n=11)$. Results: A logistic regression analysis revealed that the APACHE II score, outcome, and the rate of change of the area of the psoas major were factors relevant to ambulation independence. Conclusion: As decreases in the cross-sectional area of the psoas major during intensive care possibly affect patients' gait ability after being discharged from the ICU, it may be necessary to prevent any loss of the psoas major muscle strength by promoting early mobilization whenever possible or, if not possible, actively providing in-bed muscle training even for ICU patients.

Key words: (1) colon perforation, (2) muscle weakness, (3) psoas major, (4)early mobilization

J Jpn Soc Intensive Care Med 2016;23:554-60. 